\title{
Effects of Parent Attitude on Secondary School Students Academic Performance in Pakistan
}

\author{
Gulzar Ahmed', Muhammad Arshad ${ }^{2 *}$, Zia Ahmad Qamar ${ }^{3}$ and Muhammad Arif ${ }^{4}$ \\ 'University of Lahore, Pakpattan Campus, Pakistan; dr.gulzar2016@gmail.com \\ 25ST Science, Government Fazilka Islamia Model High School, Pakpattan, Punjab, Pakistan; \\ marshadzakki@gmail.com \\ ${ }^{3}$ Government High School, No.1 Haveli Lakha, Okara, Pakistan; ziahmadqamar@gmail.com \\ ${ }^{4}$ University of Lahore-Pakistan; razamarif@gmail.com
}

\begin{abstract}
Objective: Parents played fundamental role for uplifting moral values, shaping personality as well as their academic attainment. Study was conducted to find out effects of parental attitude on students' academic performance. Methodology: Population of the study comprised on all public and private sector teachers teaching secondary classes and parents of students studying in Sahiwal division educational institutions at secondary level. Sample of the study consisted of 180 respondents ( 90 teachers and 90 parents) taken from 30 schools selected on random basis. Two types of research instruments (questionnaires and structured interview schedules) were developed and administered for getting required information. Findings: Parents' positive attitude has positive impacts for uplifting academic performance of the children but their passive attitude becomes the cause of downgrading their academic performance. Their positive attitude provides love, security, simulation, encouragement and opportunities that help children to do well for producing good results. The study concluded that children who perceived their parents as loving, accepting, encouraging and less controlling behavioral and psychological less hostile perform better in school and feel more competent. Improvements: Parents are urging to get more involved in the monitoring, supervision and should provide moral and material support to pave the path for their children's performance better in their learning.
\end{abstract}

Keywords: Academic Performance, Attitude, Impacts, Loving, Secondary Level

\section{Introduction}

Education plays leading role for uplifting economic stability and social standard of the people. It gives insight to groom the personality, upgrade moral values, insert knowledge and furnish skills to meet the demands of the society. It helps in integrating knowledge, skills, progress and prosperity of the people. The knowledge enables individual potential to utilize the skills and expertise to achieve their objectives in due course of time. It opens door of opportunity to individuals of the society to achieve better prospects in career growth. Gaining education enhances the abilities of an individual to live in a respectful way in the society ${ }^{1}$. In ${ }^{2}$ parents essential responsibility is to the improvement of their children academic performance.

Parents should make the most of positive parenting practices for grooming their children to live life in successive way. Upcoming generation could be the positive feature of any nation, therefore they require to know-how a vigorous and constructive psycho-social development, which make possible for them to be successful in overall performance of life as well as academic activities. It has been understood that educational accomplishment of students may not only depend on the superiority of schools and the teachers but also the level of parental participation has extremely necessary to development of their

${ }^{*}$ Author for correspondence 
personality and attainment and educational achievement of their children. The main factors creating hindrances for improving students' performance regarding parental attitude are parenting style, parental expectations and aspirations, home rules and parental monitoring, supervision, effective communication between parents and children, children's home activities, parental attitude towards school (checking children's homework, parents' communication with teachers and parental involvement in children's school activities. He further described that an authoritative parenting style, parental high expectations in achieving excellent school results, future plans to achieve excellent performance, neglecting the moderating role of some socio-demographic factors as family structure or socio-economic status, number of children in the family, etc ${ }^{3}$.

Parents play a very significant role in the overall learning of their children. Parental consideration makes their children; more successive in academic achievements. It is important to teach parents' that how to organize their parenting attitudes and capabilities and how to provide physical and sentimental support for their future generation ${ }^{4}$. It was also supported by ${ }^{\frac{5}{4}}$ parents have desired to do something better for their children according to their accessible resources, family background, family social and economic status, home environment and their awareness about the importance of education. The finding was in favor that parental positive attitudes such as participation of parents and background of the family have huge effects on students' educational accomplishment and to establish their status in the society ${ }^{6}$. Mostly this research study focused to determine the poor facilities in the home and lack of financial support and parental ignorance are the basic reasons of poor educational performance students at secondary school level. $\mathrm{In}^{7}$ described that parents should be able to understand the children concerning factors such as educational, psychological, physical, material, social and spiritual needs for fruitful performance in the class, school and society. $\operatorname{In}^{8}$ person responsible for transformation of knowledge to the future generation called "teacher". A teacher is one who has a positive outcome on students' learning and improvement from beginning to end an arrangement of their study matters. Teachers are lifetime learner in their subject areas, teach with dedication and are reflective upon their teaching practice, diagnostic skills, understanding of different learning methods and cultural influences. They set high expectations and support to students in attaining achievements.
To sum up it was revealed from over viewing various studies that there were many factors responsible for creating hindrances for improving students' learning outcomes but parents play significant role to upgrade children academic performance.

Parents' positive attitude help children to go ahead in the continuity of education for meeting the demands of the society, but their passive attitude can cause for lower grading their academic achievements. Children considered the backbone of any society, shouldering future responsibility to play their role by physically participating in state and society affairs. There are many facts responsible for improving children of educational standards and includes teachers' physical and instructional facilities and parents $s^{9}$. In ${ }^{10}$ role of parents is really huge not only on educating their children but also grooming and training them to be a better human being. In our society, the majority of families do not care the learning of their children. Some of the parents have incorrect opinion regarding their child performance because they do not aware with and look like to accomplish their role of supervision and encouragement in the performance of their children in schools. Parents play active role in provision of facilities to their children helpful to activate their educational activities high and sky for achieving excellence research.

Parental attitudes, behaviors and actions in relative to their children education has a substantially impact on children' learning and educational achievements ${ }^{11}$. It directly leads to put together an environmental understanding of child development to indicate how individuals, families, schools and communities act together through the educational procedure and how to contribute in different ways to children learning outcomes. Parents play a fundamental role in the shaping of personality and the Childs' intellectually development ${ }^{12}$ of children education. They play an important role as a stakeholder so their style of natural parenting and mutual relationship between themselves and their children have the abilities to impact their cognition and learning capabilities at the premature stages of their children's lives.

The first responsibility of the parent's role that their children be trained based on morality $\underline{\underline{13}}$. The focus of parents should be on the morally training, development of cognition and physically to their personality in the light of religious rather than to make an educated person. At the same time, in the vast part of world have a religious inheritance that presents a visualization of the purpose of being a human existence, definitely causes for leading 
a morally living and beliefs and customs that weave this vision into the basics of family living successively in this world.

Parents played ${ }^{14}$ significant role in the upbringing of their children. Habitually, children seek out to their parents for protection, direction, supervision and motivation to a successfully living life. Parents and teachers communication level should be strong that how communicate on a regular basis with the teachers of their children. Parents should be well aware about their children activities and interests that make causes to acknowledge and motivate your children in educational achievements ${ }^{15}$. The parents appreciate their child if they do well in examination $\frac{16}{16}$ and if they obtain low grades encourage them for hard work rather than criticize them. By appreciating them for their success in examination, they start to struggle more to get a hold more appreciation. Encourage their children if they fail or obtain less mark make possible them to stand again and start with new determination.

$\operatorname{In}^{17}$ positive attitude of the parents can be supportive to their children in a lot of concerning complicated cases and can be reflected in enhancement in class performance, creating curiosity among children to learn and higher achievement score in overall performance. Positive parental attitudes such as warmth, encouragement and a huge amount of sympathy are basic element in positive for not only academic performance but also in character formation affection, privacy, trustworthy, confidentiality, authority, accepting, politeness, harmony, individual freedom, maintain relationships with one another, obedience to the regulations, mutually understanding. These are some attitudes prevailing emotionally at children for good and positive family environment that the outcome of sharing general feelings and thoughts. Attitude refers to a favorable or unfavorable evaluative feedback towards something or someone, show signs of in ones viewpoint of beliefs, way of thinking and feelings or deliberated behavioral performance. While parental attitude means a combination of parental viewpoints and contribution anywhere it could be reflected throughout parental dialogue and actions and may has positive influences their children's learning outcomes. Parenting style ${ }^{\frac{18}{8}}$ refers to attitudes and behaviors that deposit the emotional environment of parent child relations for example, parental attachment, involvement, responsiveness and demanded towards their children. It is helpful ${ }^{19}$ for children the children to develop confidence, discusses and exchange views to resolve problems related to educational wellbeing that is favorable educational improvement. It was explored that the worth of the students' teacher relationship and parent and teachers' ratings of the child's performance ${ }^{20}$ in the classroom and obtaining educational achievements. In ${ }^{21}$ parental involvement can be divided in two groups, home-based involvement and school-based involvement. Home-based involvement is relation with their teachers; regularly attend the parent-teacher meetings in school, discussion with teachers concerning the taken as a whole performance in the class and school of their children, attending the school functions, program and volunteering at school. Instances of school-based involvement are such actions that happen in the gathering between the parents and the school. Involvement of home-based is such behavior that come about outside the school, like, talk about and discusses with their children that how they perform with good quality in activities at school and supports the children with their homework.

Parental involvement is meaningful for the teacher to knowing how coursework could be in appropriately and outstandingly, to knowing the teachers' anticipation and generously support. $\operatorname{In}^{22}$ parents should must involve personally their children education to provided that all required resources and gives them proper time to do within every activities and homework, expecting excellence work from your children, checking up with doubtful papers, marks, grades and frequency of nonappearance in the class and educational activities. Parental support $\frac{23}{}$ in their educational background would be in first class arrangements and second teachers teaches to the child and even leads and gives direction and guidance to them on the best way to perform with excellent in education and make available the required equipment, which are needed by the children. Students' educational performance depends upon the involvement of parents in their studious activities to achieve the better quality in academic achievements ${ }^{24}$.

The important role of parents' played for a children training and educational although they have diverse opinion about what will parent performance to promote their child's academic achievement. This research work will be providing a huge asset to the learning about attitudes of parents as a key determinant the personality of their children. This research study focuses to the explore some drawback of parenting and to give the ideas for solution of decreasing standards in education and its quality and related negative aspect of this system. This study conducted with personal concentration by the researcher, 
in the required areas. Parents are stakeholders in the child's learning and the quality of parenting and association between themselves and their children. Parents have the ability to affect their children cognition and learning capability in the beginning phase of the child's life. It is in this wise, that the study accounted here was done to evaluate the effects of parenting practices that are used for polish personality and achievement for the academic successes of their children.

\subsection{Statement of the Problem}

The first institution for the children is the lap of the mother and then the overall environment of home. It is parents who can start to develop their children behavior positively. Parents' positive attitude play leading role for uplifting children education in excellent manners, but their passive attitude creates hindrances for improving students' performance. Keeping in view, the problem stated the researcher decided to conduct a research study on "Effects of Parental Attitude on Secondary School Students Academic Performance".

\subsection{Objective of the Study}

The study was designed to achieve the following objectives:

- To explore parental attitude on students' academic performance.

- To find out effects of parental attitudes on students' academic performance at secondary level.

- To have comparison between urban and rural parental involvement in students' academic performance at secondary level.

\subsection{Research Questions of the Study}

The present study was designed to achieve answer the following questions:

- What is parental attitude on students' academic performance?

- What are the effects of parental attitude on students' academic performance at secondary level?

- What is the difference between urban and rural parental involvement in students' academic performance?

\subsection{Significance of the Study}

The research study is a great help for parents to be familiar with the essential role to use their authority and influences on their children academic performance. Results of the study help parents and teachers to be capable to successfully communicate with their children/students to know their role has significant value for researchers to play their active role in this regards stakeholders, policy makers and government officials to carry out further research in this particular area, since it offers a broader view for brining change in parental attitudes for improving children educational outcomes.

\subsection{Conceptual Framework}

This conceptual framework (Figure 1) presents throughout parents' attitudes that are depend on two variables independent variable and dependent variable. Such as parents' educational level, socio-economic level, parental mutual understanding, home environment, parenting styles and parental involvement in education are independent variables and dependent variable is students' academic performance. The interface of these variables establishes the outcome of students in educational performance as shown below.

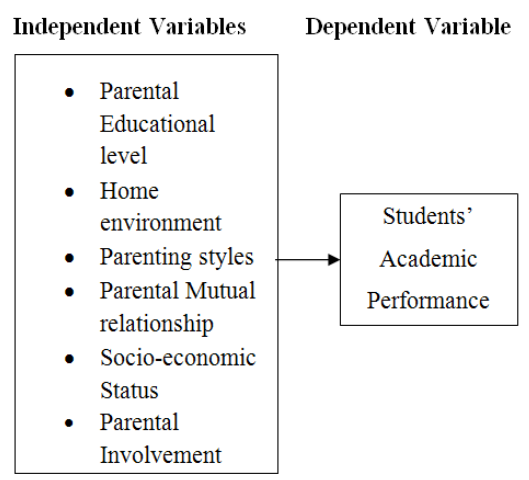

Figure 1. Conceptual framework.

\section{Research Methodology}

The design of this study was descriptive type survey in nature to collect the required data from the respective respondents. In $\frac{25}{5}$ descriptive research indicated showing careful descriptions of educational phenomena. The population of the study was comprised on parents of students studying in secondary classes and their respective teachers serving both public and private schools in three districts (Pakpattan, Sahiwal and Okara) of Sahiwal Division in central Punjab, Pakistan. The sample of the study was selected at the rate of $33 \%$ from the target population through simple random sampling technique. It 
Table 1. Data analysis for teachers (a)

\begin{tabular}{|c|c|c|c|c|c|c|c|c|}
\hline Statements & Area & SDA & DA & $\mathrm{U}$ & A & SA & Mean & SD \\
\hline \multirow{2}{*}{$\begin{array}{l}\text { Teachers regularly check student's } \\
\text { homework }\end{array}$} & Rural & 0 & 7 & 1 & 21 & 16 & 4.01 & 1.01 \\
\hline & Urban & 1 & 5 & 0 & 24 & 15 & 4.01 & 0.98 \\
\hline \multirow{2}{*}{$\begin{array}{l}\text { Teachers participate in educational } \\
\text { activities of students }\end{array}$} & Rural & 1 & 7 & 2 & 27 & 8 & 3.75 & 1.04 \\
\hline & Urban & 5 & 15 & 3 & 48 & 19 & 3.60 & 1.28 \\
\hline \multirow{2}{*}{$\begin{array}{l}\text { Teachers rarely talk to students about } \\
\text { their problems at school }\end{array}$} & Rural & 8 & 10 & 1 & 19 & 7 & 3.16 & 1.40 \\
\hline & Urban & 4 & 8 & 1 & 21 & 11 & 2.79 & 1.54 \\
\hline \multirow{2}{*}{$\begin{array}{l}\text { Teachers aware student's performance in } \\
\text { the class }\end{array}$} & Rural & 0 & 2 & 0 & 28 & 15 & 4.24 & 0.67 \\
\hline & Urban & 0 & 2 & 0 & 27 & 16 & 4.26 & 0.68 \\
\hline \multirow{2}{*}{ Teachers aware students attitudes in class } & Rural & 0 & 5 & 2 & 23 & 15 & 4.07 & 0.91 \\
\hline & Urban & 1 & 3 & 2 & 22 & 17 & 4,12 & 0.93 \\
\hline \multirow{2}{*}{$\begin{array}{l}\text { Teacher discuss with their students about } \\
\text { their studies }\end{array}$} & Rural & 10 & 10 & 1 & 15 & 9 & 3.08 & 1.55 \\
\hline & Urban & 10 & 10 & 3 & 16 & 6 & 2.96 & 1.41 \\
\hline \multirow{2}{*}{$\begin{array}{l}\text { Teachers reward students on their better } \\
\text { performance }\end{array}$} & Rural & 2 & 2 & 10 & 25 & 6 & 3.68 & 0.92 \\
\hline & Urban & 2 & 10 & 9 & 22 & 2 & 3.27 & 8.99 \\
\hline \multirow{2}{*}{$\begin{array}{l}\text { Teachers know student's educational } \\
\text { activities well }\end{array}$} & Rural & 5 & 11 & 4 & 23 & 2 & 3.12 & 1.169 \\
\hline & Urban & 3 & 14 & 2 & 20 & 6 & 4.37 & 1.05 \\
\hline \multirow{2}{*}{ Teachers understand students 'rights } & Rural & 5 & 5 & 7 & 23 & 5 & 3.39 & 1.54 \\
\hline & Urban & 2 & 5 & 10 & 20 & 8 & 3.60 & 1.45 \\
\hline \multirow{2}{*}{$\begin{array}{l}\text { Teachers discuss students' problems with } \\
\text { their parents }\end{array}$} & Rural & 17 & 4 & 1 & 19 & 4 & 2.75 & 1.06 \\
\hline & Urban & 11 & 12 & 2 & 14 & 6 & 2.81 & 1.18 \\
\hline \multirow{2}{*}{$\begin{array}{l}\text { Teachers actively involved in students' } \\
\text { learning }\end{array}$} & Rural & 3 & 3 & 4 & 26 & 9 & 3.77 & 1.04 \\
\hline & Urban & 3 & 9 & 1 & 24 & 8 & 3.56 & 1.18 \\
\hline \multirow{2}{*}{$\begin{array}{l}\text { Teachers give feedback on student's diary } \\
\text { on daily basis }\end{array}$} & Rural & 2 & 4 & 1 & 25 & 13 & 3.96 & 1.04 \\
\hline & Urban & 1 & 4 & 0 & 32 & 8 & 3.93 & 0.85 \\
\hline \multirow{2}{*}{$\begin{array}{l}\text { Parents attend parent-teacher meeting } \\
\text { regularly }\end{array}$} & Rural & 19 & 7 & 5 & 11 & 3 & 2.37 & 1.40 \\
\hline & Urban & 16 & 13 & 3 & 13 & 0 & 2.29 & 1.23 \\
\hline
\end{tabular}

comprised on 180 (90 parents +90 teachers) at the rate of 60 (30 parents +30 teachers) per district.

In this research, the researcher developed two types of research tools i.e. questionnaire for teachers and structured interview schedule for parents. The questionnaire was used for collecting data from teachers and structured interview schedules were conducted with the parents. Questionnaire was comprised on two sections. The first section of the questionnaire was regarding collection of required information on demographic data such as gender, academic qualification, professional qualification and area about teachers and parents and second section was based on their opinions about the effects of parental attitude on their children academic performance. The questionnaire administered to class teachers while parents engaged in a structured interview schedule. The structured interview schedules were conducted to take a clear image from the respondents as for as self-assessment of their children academic performance.

Reliability of the tool was determined by calculating Cronbach's Alpha. The value of Cronbach's Alpha was (0.71). Validity of the tool was determined by expert opinion. For this purpose, tool was sent to experts of the field of education and research. After receiving their expert opinion, irrelevant and double barrel statements removed and other suggested changes made.

\subsection{Presentation and Analysis of Data}

The Table 1 reflects that majority (43\%) of the urban teachers' were agreed with the statement that the respondents check the students' homework regularly. The data analysis indicates that the majority $(73 \%)$ of the urban 
Table 2. Data analysis for teachers (b)

\begin{tabular}{|c|c|c|c|c|c|c|c|c|}
\hline Statements & Area & SDA & DA & $\mathrm{U}$ & $\mathrm{A}$ & SA & Mean & $\mathrm{SD}$ \\
\hline \multirow{2}{*}{$\begin{array}{l}\text { Teachers encourage students to achieve } \\
\text { higher grade }\end{array}$} & Rural & 1 & 2 & 1 & 35 & 6 & 3.96 & 0.72 \\
\hline & Urban & 4 & 6 & 1 & 25 & 9 & 3.64 & 1.20 \\
\hline \multirow{2}{*}{$\begin{array}{l}\text { Parents visit school to discuss students' } \\
\text { academic progress }\end{array}$} & Rural & 9 & 11 & 4 & 14 & 7 & 2.98 & 1.41 \\
\hline & Urban & 23 & 7 & 1 & 12 & 2 & 2.18 & 1.40 \\
\hline \multirow{2}{*}{ Teacher monitors students' school activities } & Rural & 4 & 6 & 3 & 21 & 11 & 3.64 & 1.24 \\
\hline & Urban & 4 & 12 & 2 & 23 & 4 & 3.24 & 1.2 \\
\hline \multirow{2}{*}{$\begin{array}{l}\text { Teachers make efforts to help students' } \\
\text { learning }\end{array}$} & Rural & 2 & 0 & 0 & 34 & 9 & 4.07 & 0.78 \\
\hline & Urban & 2 & 2 & 1 & 33 & 7 & 3.91 & 0.87 \\
\hline \multirow{2}{*}{$\begin{array}{l}\text { Parents' economic status affects children } \\
\text { performance }\end{array}$} & Rural & 1 & 0 & 2 & 14 & 28 & 4.50 & 0.78 \\
\hline & Urban & 1 & 1 & 2 & 14 & 27 & 4.44 & 0.85 \\
\hline \multirow{2}{*}{$\begin{array}{l}\text { Parents encourage children to perform } \\
\text { better }\end{array}$} & Rural & 3 & 3 & 8 & 24 & 7 & 3.64 & 1.04 \\
\hline & Urban & 5 & 9 & 5 & 14 & 12 & 3.41 & 1.37 \\
\hline \multirow{2}{*}{ Teachers are committed to their profession } & Rural & 10 & 0 & 3 & 20 & 12 & 3.52 & 1.47 \\
\hline & Urban & 10 & 3 & 0 & 17 & 15 & 3.52 & 1.56 \\
\hline \multirow{2}{*}{$\begin{array}{l}\text { Teachers play an active role to improve } \\
\text { students' academic achievement }\end{array}$} & Rural & 1 & 0 & 1 & 32 & 11 & 4.16 & 0.67 \\
\hline & Urban & 1 & 2 & 2 & 26 & 11 & 4.11 & 0.84 \\
\hline \multirow{2}{*}{ Your students attend the class regularly } & Rural & 5 & 6 & 4 & 25 & 5 & 3.41 & 1.18 \\
\hline & Urban & 3 & 11 & 2 & 25 & 4 & 3.35 & 1.14 \\
\hline \multirow{2}{*}{ Students' attitude is positive with classmates } & Rural & 1 & 7 & 4 & 29 & 4 & 3.62 & 0.93 \\
\hline & Urban & 3 & 11 & 8 & 22 & 1 & 3.16 & 1.04 \\
\hline \multirow{2}{*}{ Students are responsive } & Rural & 4 & 6 & 1 & 30 & 4 & 3.52 & 1.12 \\
\hline & Urban & 1 & 12 & 2 & 25 & 5 & 3.47 & 1.07 \\
\hline \multirow{2}{*}{ Students 'attitude is positive in learning } & Rural & 3 & 6 & 3 & 27 & 6 & 3.60 & 1.09 \\
\hline & Urban & 0 & 11 & 6 & 24 & 4 & 3.47 & 0.95 \\
\hline
\end{tabular}

Table 3. Data analysis of parents' responses

\begin{tabular}{|l|l|l|c|c|c|}
\hline \multirow{2}{*}{ Statements } & \multirow{2}{*}{ Area } & \multicolumn{2}{c|}{ Yes } & \multicolumn{2}{c|}{ No } \\
\cline { 3 - 6 } & & Frequency & Percentage & Frequency & Percentage \\
\hline \multirow{2}{*}{$\begin{array}{l}\text { Do you discuss the educational } \\
\text { problems with your child? }\end{array}$} & Rural & 14 & 18 & 28 & 37 \\
\cline { 2 - 6 } & Urban & 19 & 25 & 15 & 20 \\
\hline $\begin{array}{l}\text { Do you help your child's } \\
\text { educational activities? }\end{array}$ & Rural & 16 & 21 & 21 & 28 \\
\cline { 2 - 6 } & Urban & 26 & 34 & 13 & 17 \\
\hline \multirow{2}{*}{$\begin{array}{l}\text { Does your child's educational } \\
\text { expenses create problem for you? }\end{array}$} & Rural & 35 & 46 & 7 & 9 \\
\hline & Urban & 30 & 39 & 4 & 5 \\
\hline $\begin{array}{l}\text { Child's good grades give you } \\
\text { happiness? }\end{array}$ & Rural & 42 & 55 & 0 & 0 \\
\cline { 2 - 6 } & Urban & 34 & 45 & 0 & 0 \\
\hline \multirow{2}{*}{$\begin{array}{l}\text { Is teacher's attitude good with } \\
\text { your child? }\end{array}$} & Rural & 29 & 38 & 13 & 17 \\
\cline { 2 - 6 } & Urban & 30 & 39 & 4 & 5 \\
\hline
\end{tabular}


teachers participate in educational activities of students. The respondents' response shows that the majority (35\%) of urban teachers' rarely talk to students about their problems at school. Rural and urban (48\%) teachers equally showed the results that teachers aware students' performance in the class. The analysis of data showed that the majority (43\%) of urban teachers' aware students' attitudes in class whereas the majority (27\%) of rural teachers' showed the response that the teacher discusses with their students about their studies. The study found that the majority of urban (34\%) teachers' agreed with this statement that teachers reward students on their better performance while the majority $(29 \%)$ of urban teachers' demonstrate the result that teachers know about student's educational activities well.

It was found that the rural and urban $(31 \%)$ teachers equally agree with the statement that teachers understand students 'rights whereas the majority (25\%) of rural teachers' discusses students' problems with their parents. The data of the study revealed that the majority $(39 \%)$ of rural teachers' were agreed with the statement that teachers actively involved in students' learning. The table indicates that the majority (44\%) of urban teachers' showed the results to give feedback on students' diaries on daily basis. It was revealed from the study that majority $(32 \%)$ of urban teachers were disagreed that parents attend parent-teacher meeting regularly.

Table 2 shows that the majority (45\%) of rural teachers' were agreed with the statement that teachers encourage students to achieve higher grade whereas the majority (34\%) of rural teachers' were agreed with the statement that parents visit school to discuss students' academic progress. The rural teachers (35\%) were agreed with the statement that teacher monitors students 'school activities. The analysis shows that the majority (48\%) of rural teachers' shows agree with the statement that teachers make efforts to help students' learning and majority (47\%) of rural teachers' shows agree with the statement that parents' economic status affects the performance of their children. The data of the study revealed that the majority (34\%) of rural teachers were agreed with the statement that parents encourage their children to perform better. The rural and urban (35\%) teachers agreed with the statement that teachers are committed to their profession and majority (48\%) of rural teachers' showed agree with this statement that teachers play an active role to improve students' academic achievement. The results indicated that majority (33\%) of rural teachers shows agree with the statement that your students attend the class regularly.

It shows that the majority (37\%) of rural teachers' were agreed with the statement that students' attitude is positive with classmates while the majority (38\%) of rural teachers' were agreed with the statement that students are responsive. The table portrayed that the majority (37\%) of rural teachers shows the response in the light of this statement that students 'attitude is positive in learning. Table 3 shows that the majority (37\%) of the rural parents did not discuss educational problems of their children with them, whereas the urbanized parents (25\%) discuss the educational problems with their children more than the rural parents. The rural parents (28\%) did not help their children in their educational activities, whereas urbanized parents (34\%) help their children in their educational activities. It was revealed from the analysis of the study that majority (46\%) of the urban parents bear their children educational expenses, whereas rural parents (39\%) due low income do not-do so which create problems for them. The table indicated that the equally urban and rural parents $(100 \%)$ that child's good grades gave them happiness, which has a positive impact to improve children academic performance. It was revealed from the results of the study that the urban parents $(38 \%)$ showed good attitude with their children which has positive effects whereas the majority of the rural parents (39\%) indicated positive attitude with their children which has a negative impact in uplifting the educational outcomes.

\section{Conclusions}

It was concluded that parents' positive attitude has positive impacts for uplifting academic achievements of the children but their passive attitude becomes the cause of downgrading their academic performance. It was also concluded that those parents who discuss educational problems of their children with them whereas those parents who did not discuss in this regards have negative impact on children good performance. It was further concluded that parents' physical, moral and financial support with their children encouraged children to produce better results in their studies than the parents who did not do so. It was concluded that teachers' positive attitude has positive impact on academic performance of students, whereas their harsh attitude has negative impact 
on their studies. It was further concluded that teachers who participate in discussion with students to solve their problems helped them to produce good results whereas teachers who did not bother in this regards have negative impact on students' results. It was also concluded that teachers who award students on production of good results encouraged them to more work hard and go ahead.

\section{Recommendations}

Following recommendations were made for improving students' learning outcomes:

- Parents may show positive attitudes for shaping the personality of their children physically and psychologically in order to get highest academic achievements.

- Parents may make the atmosphere of home child friendly for a better groundwork for school learning and cognitive development.

- Parent may recognize the child concerned factors such as educational, emotional, psychological, physical, material, social and spiritual needs for fruitful performance in the class, school and society.

- Parents may make sure to give learning facilities and opportunities to their children at home in order to peaceful environment.

- The government of Pakistan may establish the centers to provide of training, courses, seminars, workshops for the illiterate parents to improve the academic level of some illiterate parents to know the necessary roles of them so that they should play in the improvement of their children's academic performance.

\section{References}

1. Bakar N, Mamat I, Ibrahim M. Influence of parental education on academic performance of secondary school students in Kuala Terengganu. International Journal of Academic Research in Business and Social Sciences. 2017; 7(8):296-304. https://doi.org/10.6007/IJARBSS/v7-i8/3230

2. Ding G. Parental behaviors and academic achievement. American International Journal of Social Science. 2014; 3(1):25-43.

3. Porumbu D. Necsoi V. Relationship between parental involvement/attitude and children's school achievements.
ProcediaSocialand Behavioral Sciences. 2013;76(1):706-10. https://doi.org/10.1016/j.sbspro.2013.04.191

4. Samal R. Parents' attitude towards schooling and education of children. [Doctoral dissertation]. 2012. p. 1-50.

5. Ogunsola K, Osuolale A, Ojo O. Parental and related factors affecting students' academic achievement in Oyo State, Nigeria. International Journal of Social, Behavioral, Educational, Economic, Business and Industrial Engineering. 2014; 8(9):3129-36.

6. Akinc $Z$. The effect of parents approach on children academic achievement. IJAMRR. 2015; 3(4):1-49.

7. Jafarov J. Factors affecting parental involvement in education: The analysis of literature. Journal of Humanities and Social Sciences. $2015 ; 18(4): 1-8$.

8. Malik R. The system of education in Pakistan. National Book Foundation; 2000. p. 1-43. PMid: 10711571.

9. Home environmental factors affecting students' academic performance in Abia State, Nigeria. 2014. http://agris.fao. org/agris-search/search.do?recordID=LV2014000139

10. Emerson L, Fear J, Fox S, Sanders E. Parental engagement in learning and schooling: Lessons from research. A report by the Australian Research Alliance for Children and Youth (ARACY) for the Family. School and Community Partnerships Bureau; 2012. p. 1-60.

11. Examining the effects of parenting styles on academic performance of Senior High School students in the EjisuJuaben Municipality, Ashanti Region. 2013. http://ir.knust. edu.gh/xmlui/handle/123456789/6533?show=full

12. Ejedegba O. Influence of parental background on secondary school student's academic achievement. Abuja, Nigeria. 2017; 3(1):1-7.

13. Ntitika L. Parental characteristics influencing students' academic performance in public secondary schools in Isinya district, Kenya. A Research Report by the University of Nairobi; 2014. p. 1-100.

14. Grace M, Jethro O, Aina F. Roles of parent on the academic performance of pupils in elementary schools. International Journal of Academic Research in Business and Social Sciences. 2012; 2(1):1-6.

15. Carbonel G, Banggawan L, Agbisit I. Parents' role in enhancing the academic performance of students in the study of mathematics in Tabuk City, Philippines. International Journal of Advanced Research in Management and Social Sciences. 2013; 2(8):88-93.

16. Mpiluka A. Assessing parental involvement and its effect on Pupils' academic performance in primary school in Matamba Ward: Makete District. [Doctoral dissertation]. The Open University of Tanzania; 2014. p. 1-74.

17. Edward O, Moses P, Dinah W. Relation between parents' attitude towards educational involvement and academic performance of day secondary school students in Samia, 
Kenya. International Journal of Human Resource Studies. 2014; 4(3):147-57. https://doi.org/10.5296/ijhrs.v4i3.5964

18. Afsha JSM. Disciplinary practices of private secondary school teachers in Tacloban city in coping with students behavioral problems: Their effects on academic performance. Pakistan Journal of Education. 2008; 25(1):33-46.

19. Topor R, Keane P, Shelton L, Calkins D. Parent involvement and student academic performance: A multiple mediational analysis. Journal of Prevention and Intervention in the Community. 2010; 38(3):183-97. PMid: 20603757 PMCid: PMC3020099. https://doi.org/10.1080/10852352. 2010.486297

20. Tornblad H,Widell K. Education is the key of life: A minor field study about the discourses of parental involvement in two Tanzanian primary schools. [Unpublished Thesis (BA)]. University Skovde; 2013. p. 1-74.

21. Shami A. Development of Education in Pakistan. Academy of Educational Planning and Management. Ministry of Education: Islamabad. 2005, pp. 8-88.
22. Stanislaus J. Influence of parental socio-economic status on students' academic performance in public secondary schools in Tana River County, Kenya. A research project submitted in University of Nairobi. 2016; 6(3):154-69.

23. McNeal B, Jr. Parent involvement, academic achievement and the role of student's attitudes and behaviors as mediators. Universal Journal of Educational Research. 2014; 2(8):564-76.

24. Mutodi P, Ngirande H. The impact of parental involvement on student performance: A case study of a South African Secondary School. Mediterranean Journal of Social Sciences. 2014; 5(8):1-11. https://doi.org/10.5901/ mjss.2014.v5n8p279

25. Gay LR. Educational research: Competencies for analysis and application. 10th Ed. Pearson; 2011. p. 1-672. PMid: 20880496. 